\title{
Front Matter: Volume 10472
}

, "Front Matter: Volume 10472," Proc. SPIE 10472, Diagnosis and Treatment of Diseases in the Breast and Reproductive System IV, 1047201 (2 May 2018); doi: 10.1117/12.2315709

SPIE. Event: SPIE BiOS, 2018, San Francisco, California, United States 


\title{
PROGRESS IN BIOMEDICAL OPTICS AND IMAGING

\section{Diagnosis and Treatment of Diseases in the Breast and Reproductive System IV}

\author{
Melissa C. Skala \\ Paul J. Campagnola \\ Editors
}

\section{7-28 January 2018}

San Francisco, California, United States

Sponsored by

SPIE

Cosponsored by

Applied Scientific Instrumentation (United States)

Bruker (United States)

Thorlabs (United States)

Chroma Technology Corporation (United States)

Published by

SPIE 
The papers in this volume were part of the technical conference cited on the cover and title page. Papers were selected and subject to review by the editors and conference program committee. Some conference presentations may not be available for publication. Additional papers and presentation recordings may be available online in the SPIE Digital Library at SPIEDigitalLibrary.org.

The papers reflect the work and thoughts of the authors and are published herein as submitted. The publisher is not responsible for the validity of the information or for any outcomes resulting from reliance thereon.

Please use the following format to cite material from these proceedings:

Author(s), "Title of Paper," in Diagnosis and Treatment of Diseases in the Breast and Reproductive System IV, edited by Melissa C. Skala, Paul J. Campagnola, Proceedings of SPIE Vol. 10472 (SPIE, Bellingham, WA, 2018) Seven-digit Article CID Number.

ISSN: 1605-7422

ISSN: 1996-756X (electronic)

ISBN: 9781510614291

ISBN: 9781510614307 (electronic)

Published by

SPIE

P.O. Box 10, Bellingham, Washington $98227-0010$ USA

Telephone +1 3606763290 (Pacific Time) · Fax +1 3606471445

SPIE.org

Copyright (c) 2018, Society of Photo-Optical Instrumentation Engineers.

Copying of material in this book for internal or personal use, or for the internal or personal use of specific clients, beyond the fair use provisions granted by the U.S. Copyright Law is authorized by SPIE subject to payment of copying fees. The Transactional Reporting Service base fee for this volume is $\$ 18.00$ per article (or portion thereof), which should be paid directly to the Copyright Clearance Center (CCC), 222 Rosewood Drive, Danvers, MA 01923. Payment may also be made electronically through CCC Online at copyright.com. Other copying for republication, resale, advertising or promotion, or any form of systematic or multiple reproduction of any material in this book is prohibited except with permission in writing from the publisher. The CCC fee code is 1605$7422 / 18 / \$ 18.00$.

Printed in the United States of America.

Publication of record for individual papers is online in the SPIE Digital Library.

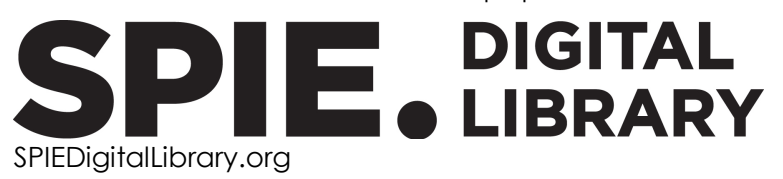

Paper Numbering: Proceedings of SPIE follow an e-First publication model. A unique citation identifier (CID) number is assigned to each article at the time of publication. Utilization of CIDs allows articles to be fully citable as soon as they are published online, and connects the same identifier to all online and print versions of the publication. SPIE uses a seven-digit CID article numbering system structured as follows:

- The first five digits correspond to the SPIE volume number.

- The last two digits indicate publication order within the volume using a Base 36 numbering system employing both numerals and letters. These two-number sets start with 00, 01, 02, 03, 04, 05, 06, 07, 08, 09, OA, OB ... OZ, followed by 10-1Z, 20-2Z, etc. The CID Number appears on each page of the manuscript. 


\title{
Contents
}

\author{
$\checkmark$ Authors \\ vii Conference Committee
}

\section{GYNOCOLOGY}

1047204 Evaluation of segmentation algorithms for optical coherence tomography images of ovarian tissue [10472-1]

\section{BREAST CANCER}

$10472 \mathrm{OE}$ Intravital imaging of tumor bioenergetics in metastatic and non-metastatic breast cancer [10472-11]

\section{DEVELOPMENTAL BIOLOGY AND PEDIATRICS}

10472 OL Using a wearable near-infrared spectroscopy device in children with Tourette syndrome [10472-18]

1047200 A potential non-invasive approach to evaluating blastocyst quality using biodynamic imaging [10472-21]

\section{CARDIAC DEVELOPMENTAL BIOLOGY}

10472 OS Live dynamic analysis of mouse embryonic cardiogenesis with functional optical coherence tomography [10472-26]

\section{POSTER SESSION}

10472 OU Optical redox imaging of fixed unstained tissue slides to identify biomarkers for breast cancer diagnosis/prognosis: feasibility study [10472-28]

$10472 \mathrm{OV}$ Optical imaging of metabolic adaptability in metastatic and non-metastatic breast cancer [10472-29] 
Proc. of SPIE Vol. 10472 1047201-4 Downloaded From: https://www.spiedigitallibrary.org/conference-proceedings-of-spie on 26 Apr 2023
Terms of Use: https://www.spiedigitallibrary.org/terms-of-use 


\section{Authors}

Numbers in the index correspond to the last two digits of the seven-digit citation identifier (CID) article numbering system used in Proceedings of SPIE. The first five digits reflect the volume number. Base 36 numbering is employed for the last two digits and indicates the order of articles within the volume. Numbers start with 00, 01, 02, 03, 04, 05, 06, 07, 08, 09, OA, OB...0Z, followed by 10-12, 20-2Z, etc.

Barton, Jennifer K., 04

Baur, Joseph A., OU

Cheong, Pou-Leng, OL

Ehmke, Natalie, 00

Feng, Min, OU

Harper, Mason, OE

Koevary, Jennifer W., 04

Larina, Irina $V_{\text {., }}$ OS

Li, Lin Z., OU

$\mathrm{Li}$, Ting-Yi, OL

$\mathrm{Li}$, Yusheng, OU

$\mathrm{Li}$, Zhe, 00

Lopez, Andrew L., III, OS

Machaty, Zoltan, 00

Nolte, David, 00

Quinn, William J., III OU

Rajaram, Narasimhan, OE, OV

Rasul, Raisa, OE

Rebello, Lisa, OV

Rice, Photini F. S., 04

Sawyer, David M., 04

Sawyer, Travis W., 04

Sun, Chia-Wei, OL

Tchou, Julia, OU

Wang, Shang, OS

$\mathrm{Xu}, \mathrm{He}$ N., OU

Zhang, Paul, OU 
Proc. of SPIE Vol. 10472 1047201-6

Downloaded From: https://www.spiedigitallibrary.org/conference-proceedings-of-spie on 26 Apr 2023 Terms of Use: https://www.spiedigitallibrary.org/terms-of-use 


\title{
Conference Committee
}

\author{
Symposium Chairs
}

James G. Fujimoto, Massachusetts Institute of Technology

(United States)

R. Rox Anderson, Wellman Center for Photomedicine, Massachusetts General Hospital (United States) and Harvard Medical School (United States)

Program Track Chair

Brian J. F. Wong, Beckman Laser Institute and Medical Clinic (United States)

Conference Chairs

Melissa C. Skala, University of Wisconsin-Madison (United States)

Paul J. Campagnola, University of Wisconsin-Madison (United States)

\section{Conference Program Committee}

Ji-Xin Cheng, Purdue University (United States)

Kevin W. Eliceiri, University of Wisconsin-Madison (United States)

Anita Mahadevan-Jansen, Vanderbilt University (United States)

Darren M. Roblyer, Boston University (United States)

Andrew M. Rollins, Case Western Reserve University (United States)

Bruce J. Tromberg, Beckman Laser Institute and Medical Clinic (United States)

\section{Session Chairs}

1 Gynocology

Paul J. Campagnola, University of Wisconsin-Madison (United States)

2 Margin Assessment and Prostate

Kevin W. Eliceiri, University of Wisconsin-Madison (United States)

3 Breast Cancer

Darren M. Roblyer, Boston University (United States)

4 Breast Cancer Surgery and Margins

Anita Mahadevan-Jansen, Vanderbilt University (United States) 
5 Developmental Biology and Pediatrics

Andrew M. Rollins, Case Western Reserve University (United States)

6 Cardiac Developmental Biology

Michael W. Jenkins, Case Western Reserve University (United States) 